\title{
Porous formation process of granules from man-triggered raw materials
}

\author{
Olga Miryuk ${ }^{*}$ \\ Rudny Industrial Institute, Kazakhstan
}

\begin{abstract}
The results of studies of porous structure formation in a granular glass mixture are presented. Raw mixes were prepared from glass cullet, waste of magnetite ores dressing and liquid glass. The reason for adding of magnetite ores waste to the glass mixture was the information on chemical and mineral composition, results of studies of thermal transformations of waste. The rationale for adding of $20-30 \%$ of magnetite ores waste into the raw mix is confirmed by lowering the bloating temperature and increasing granules porosity. The effect of pyrite mineral on structural transformations in a glass mixture has been studied for the first time. It was revealed that the presence of pyrite up to $10 \%$ in the glass mixture intensifies swelling at lower temperatures. A method for preparing a molding mixture is proposed, which ensures the formation of highly porous granules with equal distribution of cells in the structure. The method involves mechanical activation of mixture of glass cullet and magnetite ores waste by grinding in a vibratory mill and subsequent portion-wise introduction of the activated mixture into liquid glass. A complex of technological methods allows obtaining porous granules with a packed density of $300 \mathrm{~kg} / \mathrm{m}^{3}$ at a temperature of $825^{\circ} \mathrm{C}$.
\end{abstract}

\section{Introduction}

Porous granular material is basis for composites with heat-shielding properties. Silicate materials of porous structure are characterized by high strength, wide temperature range of application, increased resistance to environmental exposure. Production process for granulated foam glass [1 - 9], highly porous granular materials based on thermal swelling of liquid glass [10 - 13] are actively being developed. For implementation of thermal swelling of granules there are used gas-forming processes in components of the raw mass or special additives can be added. One of the obstacles to widespread production of foam glass is a shortage of raw materials. That is why resource-saving technologies for production of porous granules based on glass cullet are preferred. Glass cullet is represented by fragments of container and sheet glass. To regulate the material composition of the raw mix and granules porosity, additives are added into the glass cullet [14 - 19].

Waste of magnetite ores is formed during magnetic separation of mined rock. Wastes are characterized by polymineral composition and transformations in a wide temperature range [20]. Use of magnetite ores waste in the glass mixture is of scientific and practical interest.

\footnotetext{
* Corresponding author: psm58@mail.ru
} 


\section{Materials and methods of research}

Raw materials were prepared from glass cullet and waste of magnetite ores dressing (table 1). Magnetite ores wastes are fine particles no larger than $0.55 \mathrm{~mm}$ in size, which are formed during magnetic separation of mined rock. Mineral composition of waste is represented by calcium silicates and aluminosilicates (diopside, grossular, epidote, scapolite, chlorite, field spar). Waste contains $10-15 \%$ of pyrite, up to $8-10 \%$ of calcite and $2-4 \%$ of magnetite. Raw materials were crushed to a specific surface of $350-370$ $\mathrm{m}^{2} / \mathrm{kg}$. The specific surface of powders was evaluated on a photosydentiometer.

Table 1. Chemical composition of raw materials.

\begin{tabular}{|c|c|c|c|c|c|c|c|c|c|}
\hline \multirow[b]{2}{*}{ Material } & \multicolumn{9}{|c|}{ Oxides content, \% } \\
\hline & $\mathrm{SiO}_{2}$ & $\mathbf{A l}_{2} \mathbf{O}_{3}$ & $\mathrm{Fe}_{2} \mathrm{O}_{3}$ & $\mathrm{CaO}$ & MgO & $\mathbf{R}_{2} \mathbf{O}$ & $\mathrm{SO}_{3}$ & other & $\begin{array}{l}\text { weight } \\
\text { reduction } \\
\text { when } \\
\text { calcined }\end{array}$ \\
\hline Glass cullet & 73.2 & 2.3 & 0.2 & 7.2 & 3.7 & 13.2 & 0.1 & 0.1 & - \\
\hline $\begin{array}{l}\text { Waste of } \\
\text { magnetite ores } \\
\text { dressing }\end{array}$ & 35.7 & 9.2 & 16.7 & 10.5 & 5.2 & 1.5 & 15.7 & 1.4 & 4.1 \\
\hline
\end{tabular}

Raw mix was obtained by thorough mixing of the components. Liquid glass - an aqueous solution of sodium silicate $\left(\mathrm{Na}_{2} \mathrm{O} \cdot \mathrm{mSiO}_{2}+\mathrm{mH}_{2} \mathrm{O}\right)$ with a density of $1400 \mathrm{~kg} / \mathrm{m}^{3}$ was added to form powdered raw mass and to thermally swell the granules. The content of liquid glass in a mixture is $30-40 \%$. Raw mix was prepared in the form of granules with a diameter of $10 \mathrm{~mm}$. The dried granules were burned in a laboratory oven at a given temperature with isothermal aging for 15 minutes. Pyrogenic transformations in a raw mixture were studied with the differential thermal analysis method, which was carried out on a derivatograph of the Q -1500 D of system F. Paulik, J. Paulik, L. Erdey.

Microstructure of the sintered pellets was investigated by electron microscopy. Swelling coefficient was defined as the ratio of granules sizes before and after firing. Thermal transformations in the raw mass were evaluated by the nature of porous structure and density of granules. The average pore size was determined by 11 measurements in the photograph of granules cleavage.

\section{Results and discussion}

The object of the study was porous granules obtained from glass mixture. The purpose of the work is to study the effect of magnetite ores waste on the process of porous structure formation and properties of granules. Research is focused on synthesis of porous granules with packed density up to $300 \mathrm{~kg} / \mathrm{m}^{3}$, intended for use as an aggregate for lightweight concrete.

\subsection{Influencing of magnetite ores waste on porous formation process of granules}

Choice of waste magnetite ores as an additive to the glass mixture is due to gas-forming minerals presence. Exothermic effect on a thermo gram at $500^{\circ} \mathrm{C}$ characterizes pyrite oxidation (figure 1). In the temperature range of $550-800^{\circ} \mathrm{C}$ endothermic reactions of aluminosilicates dehydration occur and calcite decomposition takes place. 


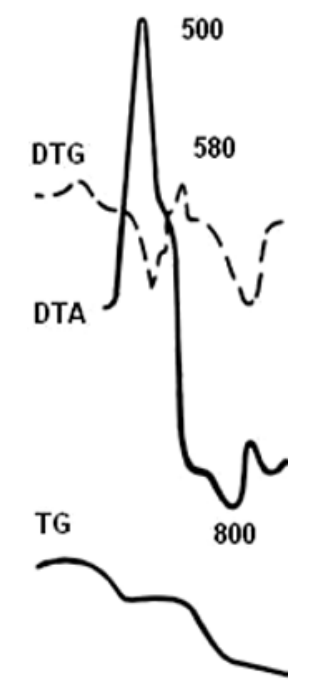

Fig. 1. Thermogram of waste of magnetite ores dressing.

Table 2. Different additives influence on granules swelling.

\begin{tabular}{|l|c|c|c|c|}
\hline \multirow{3}{*}{ Additive } & \multirow{2}{*}{$\begin{array}{c}\text { Additive content } \\
\text { in glass mixture, }\end{array}$} & \multicolumn{3}{c|}{$\begin{array}{c}\text { Swelling coefficient } \\
\text { at a temperature of burning, }{ }^{\mathbf{~}} \mathbf{C}\end{array}$} \\
\cline { 2 - 5 } & & $\mathbf{8 0 0}$ & $\mathbf{8 5 0}$ & $\mathbf{9 0 0}$ \\
\hline No additives & 0 & 1.30 & 1.50 & 1.70 \\
\hline \multirow{4}{*}{ Magnetite ores waste } & 10 & 1.35 & 1.57 & 1.70 \\
\cline { 2 - 5 } & 20 & 1.38 & 1.60 & 1.67 \\
\cline { 2 - 5 } & 30 & 1.43 & 1.62 & 1.56 \\
\cline { 2 - 5 } & 40 & 1.25 & 1.57 & 1.70 \\
\hline \multirow{4}{*}{ Pyroschist } & 10 & 1.30 & 1.38 & 1.65 \\
\cline { 2 - 5 } & 20 & 1.32 & 1.40 & 1.65 \\
\cline { 2 - 5 } & 30 & 1.35 & 1.52 & 1.56 \\
\cline { 2 - 5 } & 40 & 1.20 & 1.35 & 1.42 \\
\cline { 2 - 5 } & 10 & 1.24 & 1.40 & 1.60 \\
\cline { 2 - 5 } & 20 & 1.35 & 1.50 & 1.71 \\
\cline { 2 - 5 } & 30 & 1.28 & 1.47 & 1.60 \\
\cline { 2 - 5 } & 40 & 1.05 & 1.30 & 1.24 \\
\hline
\end{tabular}

Ambiguous nature of change in mass when heated indicates magnetite oxidation (mass increases at temperatures of $300-400^{\circ} \mathrm{C}$ ) and decomposition of pyrite, accompanied by partial removal of gaseous products (mass reduction is at temperatures of $400-500^{\circ} \mathrm{C}$ ). With further heating of waste to a temperature of $580^{\circ} \mathrm{C}$ there is an increase in mass due to oxidation of $\mathrm{FeO}$.

Studies have shown that the effect of magnetite ores waste on swelling of granules is more effective compared to traditional additives (table 2). The effect of waste is in decrease of mass softening temperature by $25-30^{\circ} \mathrm{C}$, and increase in granules' porousness. The optimum content of ore dressing waste in the mixture is $20-30 \%$; it provides the highest coefficient of swelling, equal cellular structure (figure 2). With increase of waste in the content of granules' structure, pinholes are formed and burned granules are destroyed.

Increased porousness of waste-based granules is ensured by participation in the process of gaseous substances formed during thermal decomposition of minerals (figure 1). An additional amount of pores in granules is formed by carbon dioxide released during calcite decarbonization; with the participation of water vapour in dehydration of minerals (chlorite, epidote, amphibole); as a result of pyrite oxidation. 


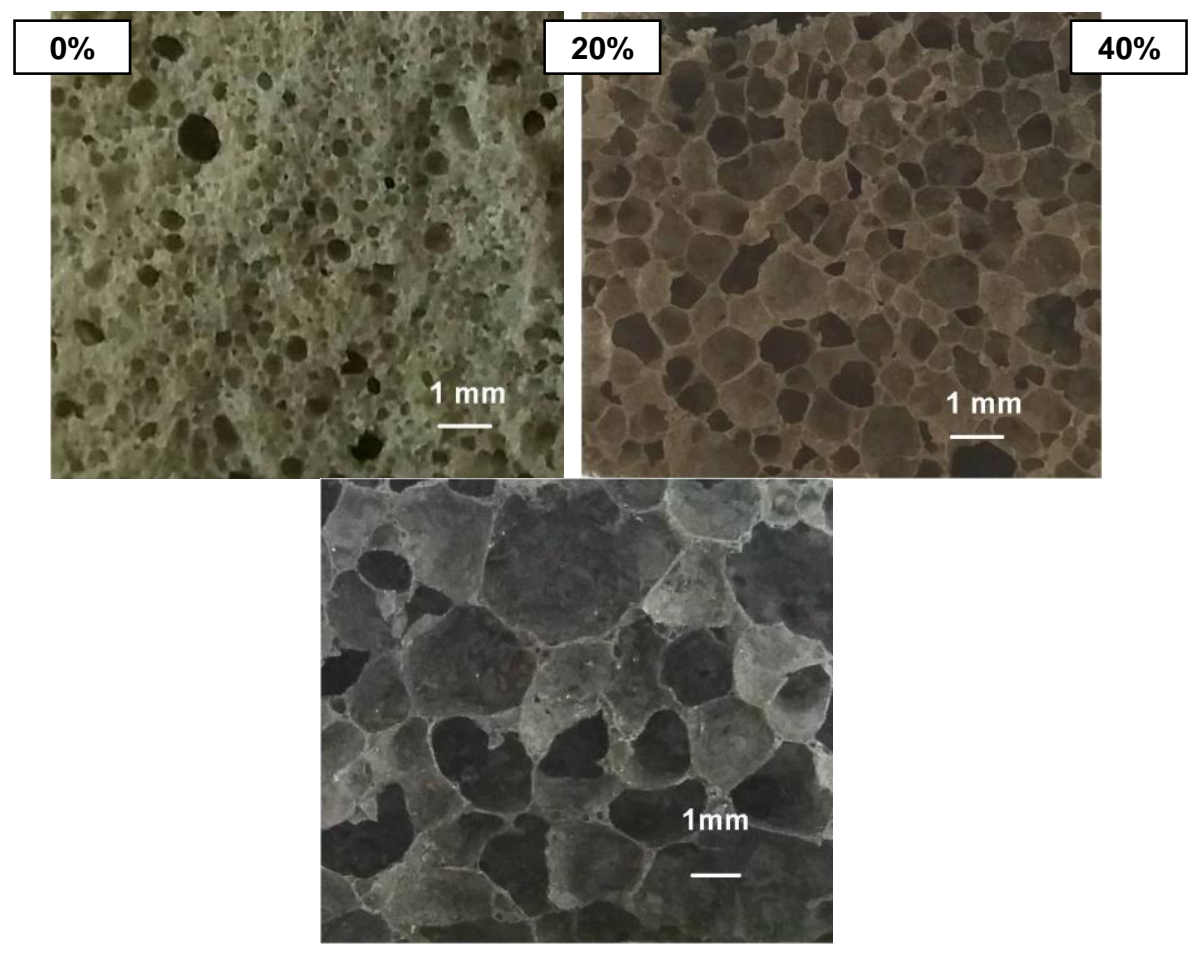

Fig. 2. Structure of granules with different content of magnetite ores waste.

The nature of porousness involving carbon dioxide and water vapour is known [1 -7]. Formation of porous structure in glass granules due to pyrite has not been studied.

\subsection{Effect of pyrite additive on granules swelling}

Pyrite $\mathrm{FeS}_{2}$ is a common sulphide of the earth's crust. The process of thermal decomposition of pyrite is a multistage process. The removal of sulfur from pyrite occurs at a temperature of $500^{\circ} \mathrm{C}$, then the following reactions proceed [20]:

$$
\begin{gathered}
\mathrm{S}_{2}+2 \mathrm{O}_{2} \rightarrow 2 \mathrm{SO}_{2}, \\
\mathrm{FeS}+1.5 \mathrm{O}_{2} \rightarrow \mathrm{FeO}+\mathrm{SO}_{2} .
\end{gathered}
$$

General scheme of pyrite oxidation process:

$$
4 \mathrm{FeS}_{2}+11 \mathrm{O}_{2} \rightarrow 2 \mathrm{~F}_{2} \mathrm{O}_{3}+8 \mathrm{SO}_{2}
$$

Low-temperature gas formation in pyrite is of interest for porous structure formation during foaming of glass mass.

Model raw material mixtures from glass and pyrite cullet were investigated. Mineral pyrite was added in the amount of 5,10 and $15 \%$. The content of liquid glass in a mixture is $35 \%$. The intensity of exothermic effects at $300-600^{\circ} \mathrm{C}$ indicates a significant heat release in the process of pyrite oxidation. This contributed to decrease in softening temperature of glass mass and increase in porosity, and decrease in granules density (figure 3). To obtain equal porousness and lowest density, glass batches with $10 \%$ of pyrite are preferred (figure 4). 


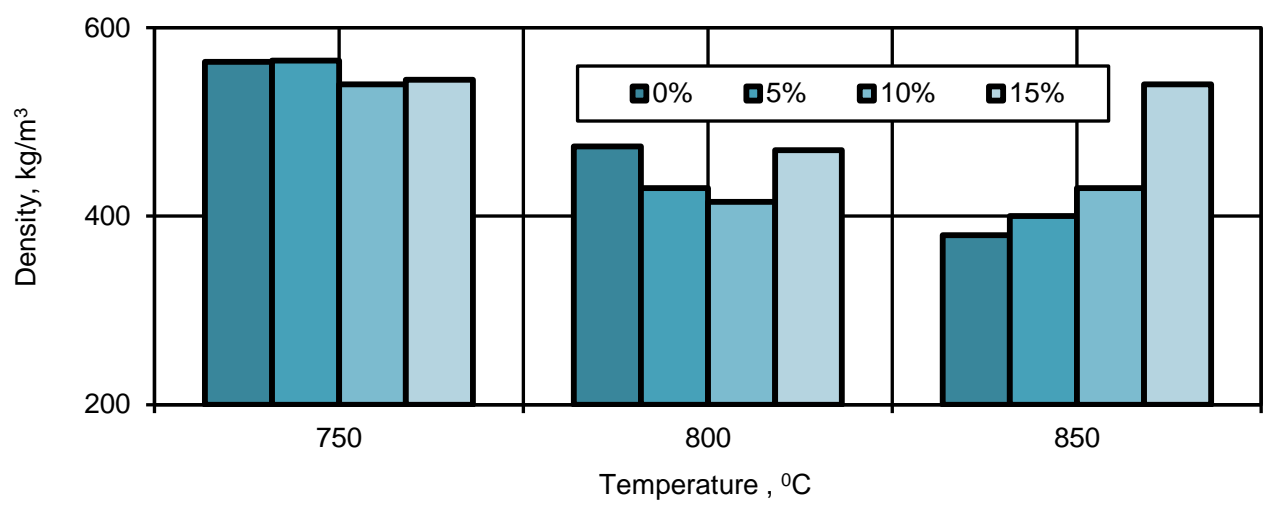

Fig. 3. The effect of pyrite additive on density of burnt granules.

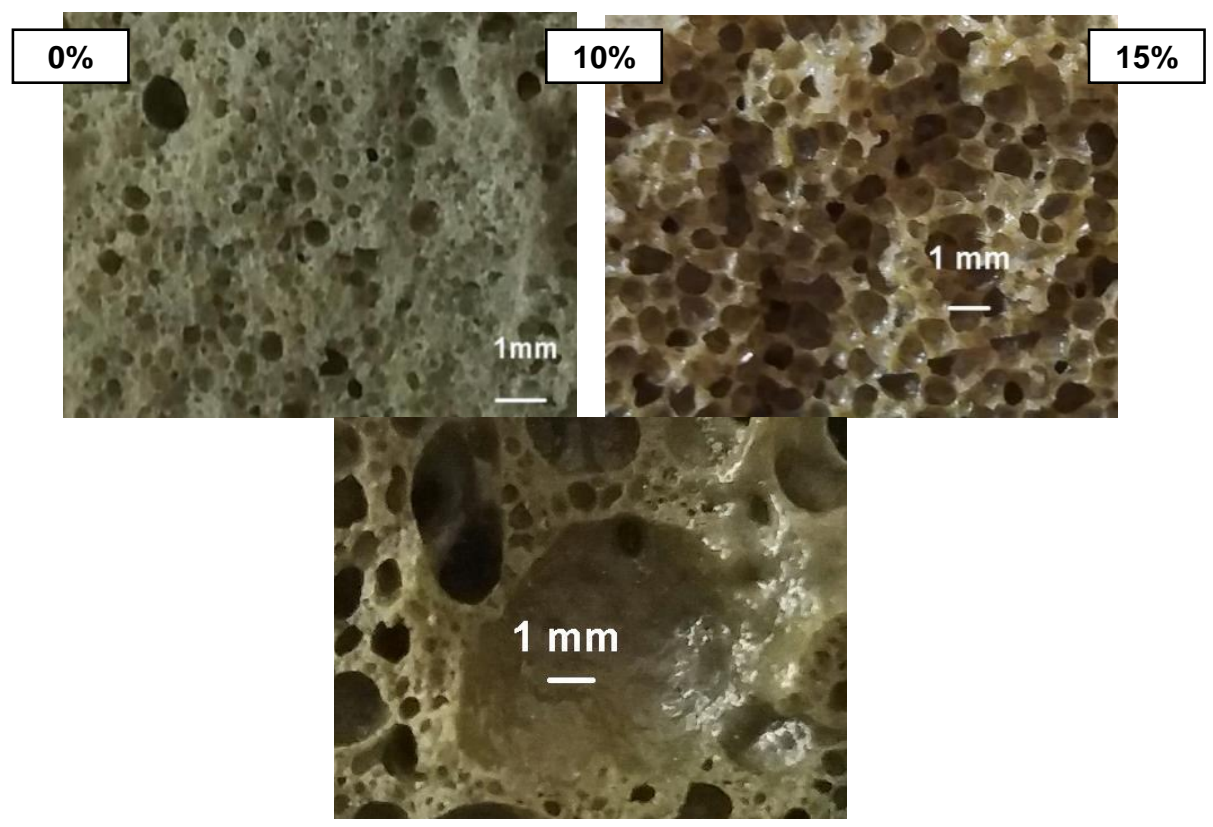

Fig. 4. Structure of granules with different content of pyrite in the raw mix.

Increase in content of pyrite in excess of $10 \%$, increase in temperature to $850^{\circ} \mathrm{C}$ is accompanied by melting and decrease in porousness of granules. Therefore, adding of pyrite into the glass batch provides additional source of gas formation, contributes to granules swelling at a low temperature.

\subsection{Influence of the method of raw mix preparation on porosity and properties of granules}

Formation of porous structure of granules is a complex process, depending on dispersion of raw materials, method of raw mix preparation. The effect of intensive grinding of raw materials in the vibration mill «Emax» was investigated. As a result of grinding raw materials in a vibratory mill, the specific surface of the materials increased, reactivity of mixture increased during burning (table 3). Increase in dispersion of raw materials contributes to porosity of granules at low temperatures. Joint grinding of components is preferred, which provides activation of the raw mix, reducing burning temperature by $50^{\circ} \mathrm{C}$, 
increasing a swelling coefficient, reducing the pore size from 1.2 to $0.7 \mathrm{~mm}$.

Table 3. Effect of intensive grinding of raw materials on granules porosity.

\begin{tabular}{|l|c|c|c|c|}
\hline \multirow{2}{*}{\begin{tabular}{c}
\multirow{2}{*}{$\begin{array}{c}\text { The method of raw mix } \\
\text { preparation }\end{array}$} \\
\cline { 5 - 5 }
\end{tabular}} & \multicolumn{2}{|c|}{$\begin{array}{c}\text { Specific surface, } \mathbf{~ m}^{\mathbf{2}} / \mathbf{k g} \\
\text { before } \\
\text { grinding }\end{array}$} & $\begin{array}{c}\text { after } \\
\text { grinding }\end{array}$ & \multicolumn{2}{c|}{$\begin{array}{c}\text { Swelling coefficient at a } \\
\text { burning temperature, }{ }^{\mathbf{}} \mathbf{C}\end{array}$} \\
\cline { 5 - 5 } & 360 & - & $\mathbf{8 2 5}$ & $\mathbf{8 5 0}$ \\
\hline Conventional grinding of a raw mix & 350 & 500 & 1.45 & 1.62 \\
\hline Intensive grinding of glass cullet & 370 & 515 & 1.67 & 1.77 \\
\hline $\begin{array}{l}\text { Intensive grinding of magnetite ores } \\
\text { waste }\end{array}$ & 360 & 510 & 1.80 & 1.75 \\
\hline Intensive grinding of a raw mix & &
\end{tabular}

Liquid glass is a multifunctional component of the raw mass. Liquid glass binds solid components during granules formation and ensures formation of pores during burning of the material [12]. With increase in content of liquid glass, the temperature of pyroplastic material state decreases, granules porosity increases. With introduction of liquid glass in excess of $40 \%$ the molding mixture is characterized by increased fluidity, deterioration of granules stability. It was revealed that as the proportion of a liquid component increases, the average pore size increases.

Influence of the method of liquid glass adding into the raw mix on the properties of granules was investigated (figure 5). Raw materials, crushed in a vibration mill were used. It was stated that the initial mixing of liquid glass with ore dressing wastes ensures equal distribution and increase in pores size of $0.3-0.5 \mathrm{~mm}$.

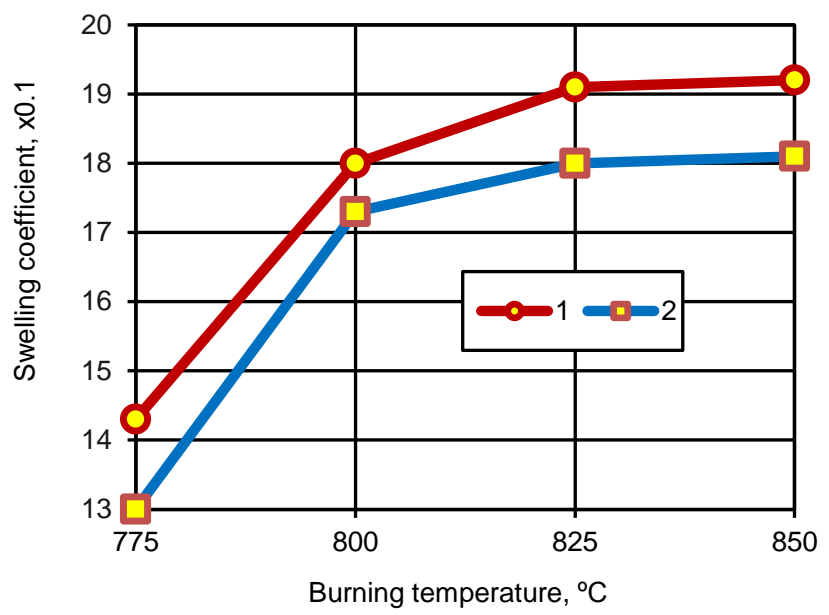

1 - phased adding of liquid glass into the activated raw mix;

2 - mixing of liquid glass with an activated raw mix

Fig. 5. Effect of raw material preparation method on granules swelling.

When mixing the liquid component with glass cullet, the molding properties of the mixture are improved. The greatest effect is achieved with phased introduction of the activated raw material mixture into the liquid component: after adding of $20 \%$ of raw mass into the liquid glass, the mixture was stirred, and $40 \%$ of raw mixture was added at subsequent stages

Advantages of gradual introduction of raw mass into the liquid glass are lowering of swelling temperature of granules, reducing granules density, increasing of small pores in the partitions between the cells (figure 6). 
Porous granules of activated raw material mixture prepared by gradual adding of liquid glass, characterized by packed density of $290-300 \mathrm{~kg} / \mathrm{m}^{3}$ (figure 7).

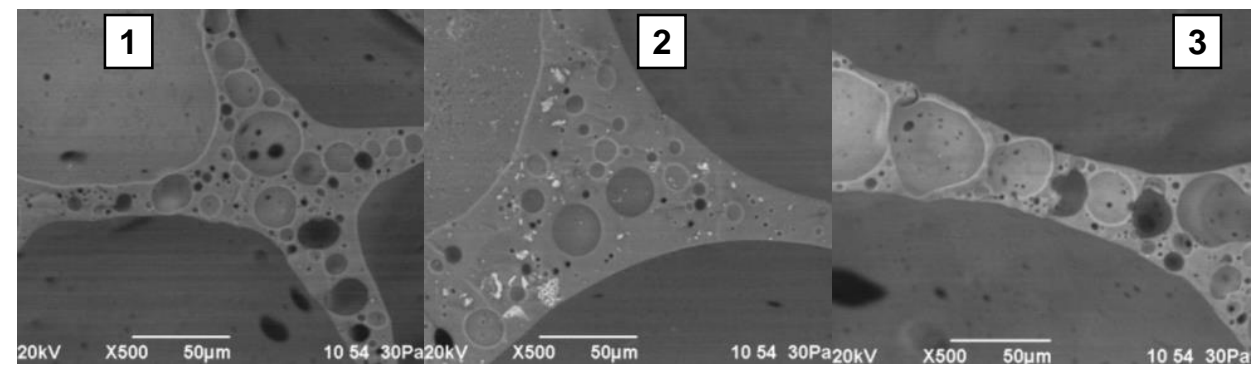

1 - gradual introduction of liquid glass into the raw material mixture activated;

2 - introducing liquid glass into the glass cullet; 3 - mixing of liquid glass with magnetite ores waste

Fig. 6. Microstructure of granules from raw mixtures prepared in various ways.
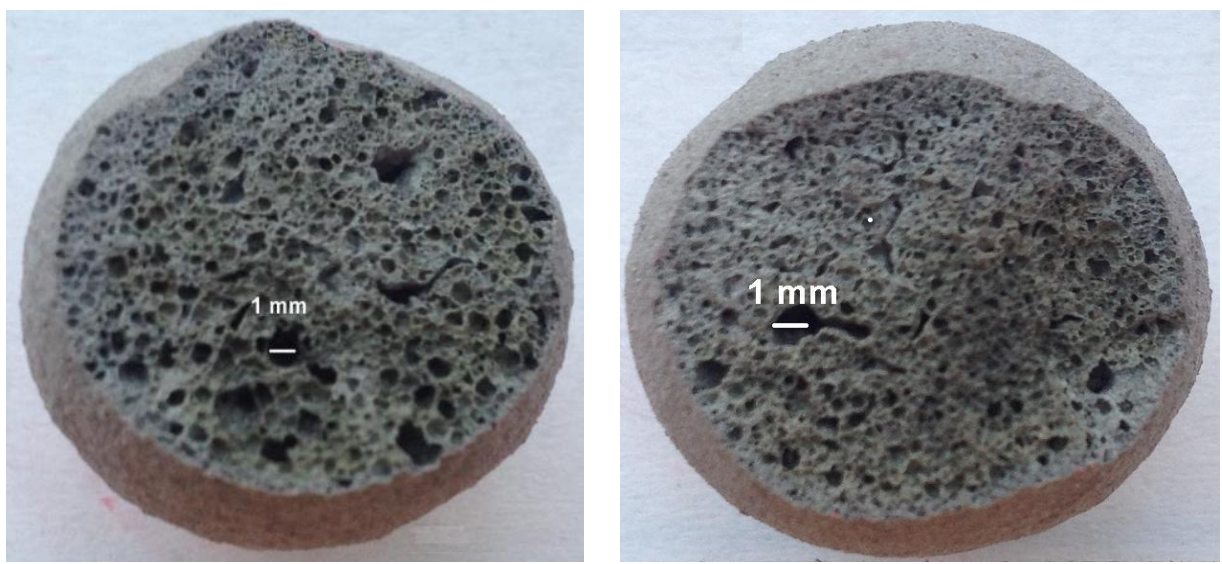

Fig. 7. Porous granules structure.

Porous structure of granules is formed by cells of various sizes and provides a material with low thermal conductivity of $0.05-0.06 \mathrm{~W} /\left(\mathrm{m} \cdot{ }^{0} \mathrm{C}\right)$. Along with the large main cells, structure of burnt material contains small pores in the partitions between the cells. Developed material is intended as an aggregate for lightweight concrete.

\section{Conclusions}

Composition of glass raw mixture containing $20-30 \%$ of waste magnetite ore has been developed to produce granulated material with packed density of $300 \mathrm{~kg} / \mathrm{m}^{3}$. Adding waste to glass batch allows you to form highly porous granules by combining various techniques.

Phase transformations of polymineral wastes are accompanied by formation of a gas phase in a wide temperature range, help reduce swelling temperature and increase granules porosity.

It was revealed that gradual introduction of activated raw material mixture into the liquid glass contributes to low-temperature formation of poly modal porosity and increase in heat-shielding properties of a granular material. 


\section{References}

1. M. Kocianova, R. Drochytka, Procedia Engineering 195, 9 - 16 (2017)

2. V.E. Manevich, R.K. Subbotin, E.A. Nikiforov, N.A. Senik, A.V. Meshkov, Glass and Ceramics 69, 168 - 172 (2012)

3. N.M. Ibrahim, K.N. Ismail, N.H. Johari, ARPN J. of Engineering and Applied Sciences 8, $5413-5417$ (2016)

4. A.R. Romero, M. Salvo, E. Bernardo, Construction and Building Materials 192,133 $140(2018)$

5. Ya.I. Vaysman, Yu.A. Ketov, V.S. Korzanov, M.P. Krasnovskih, Construction Materials 11, $64-67$ (2018)

6. C. Mugoni, M. Montorsi, C. Siligardi, F. Andreola, I. Lancellotti, E. Bernardo, L. Barbieri, Ceramics International 41, 3400 - 3408 (2015)

7. A. Rincyn, G. Giacomello, M. Pasetto, E. Bernardo, J. of the European Ceramic Society 37, $2227-2234$ (2017)

8. T. Liu, C. Lin, J. Liu, L. Han, H. Gui, C. Li, X. Zhou, H. Tang, Q. Yang, A. Lu, Ceramics International 44, 14393 - 14400 (2018)

9. V.A. Smolii, A.S. Kosarev, E.A. Yatsenko, B.N. Gol'tsman, Glass and Ceramics 75, $303-307$ (2018)

10. B.L.A. Tuan, C-L. Hwang, K-L. Lin, Y-Y. Chen, M-P. Young, Construction and Building Materials 47, $334-339$ (2013)

11. O.A. Miryuk, Inter. J. of Mechanical Engineering and Technology 8, 916 - 925 (2017)

12. S.A. Mizuriaev, A.Yu. Zhigulina, G.S. Solopova, Procedia Engineering 111, 540 - 544 (2015)

13. U.J. Alengaram, B.A. Muhit, M.Z. Jumaat, Construction and Building Materials 38, 161 $-172(2013)$

14. Y-L. Wei, S-H. Cheng, G-W. Ko, Construction and Building Materials 112, 773 - 782 (2016)

15. S.A. Montayev, B.T. Shakeshev, M.Z. Ryskaliyev, N.B. Adilova, K.A. Narikov, ARPN J. of Engineering and Applied Sciences 5, $1674-1678$ (2017)

16. M.G. Zhu, R. Ji, Z.M. Li, H. Wang, L.L. Liu, Z.T. Zhang, Construction and Building Materials 112, 398 - 405 (2016)

17. J.N. Farahani, P. Shafigh, H.B. Mahmud, Procedia Engineering 184, 778 - 783 (2017)

18. I. Kourti, C.R. Cheeseman, Resources, Conservation and Recycling 54, $769-775$ (2010)

19. C.Xi, F. Zheng, J.Xu, W. Yang, Y. Peng, Y.Li, P. Li, Q. Zhen, S. Bashir, J.L. Liu, Construction and Building Materials 190, 896 - 909 (2018)

20. O.A. Miryuk, ARPN J. of Engineering and Applied Sciences 13, 545 - 558 (2018) 